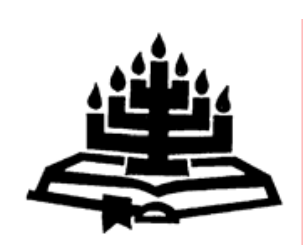

\title{
Community healing and the role of pastoral care of the ill and suffering in Africa
}

\author{
V. Magezi \\ Department of Pastoral Care \\ Bible Institute of South Africa \& George Whitfield College \\ KALK BAY \\ E-mail: vmage@bisa.org.za \\ vhumani@hotmail.com
}

\begin{abstract}
Community healing and the role of pastoral care of the ill and suffering in Africa

The extended family (community) in Africa plays a crucial role in the process of healing. However, while the role of the community is invaluable, many scholars overlook its other side. This article argues for a critical consideration of the healing role of the community in Africa and offers a critique of African community healing in the light of pastoral healing. Pastoral healing as a spiritual and faith perspective is juxtaposed with the healing process within African traditional communities. Since these two communities operate from different perspectives, in many cases they are competing forces in the process of healing - a difference that aggravates pain. This article thus carefully describes the process of healing both within a faith community (with its acts of "koinonia") and the African traditional community, and concludes by proposing a healthy integration of these systems.
\end{abstract}

\section{Opsomming}

Gemeenskapsgenesing en die rol van pastorale sorg vir die siekes en lydendes in Afrika

Die uitgebreide gesin (gemeenskap) in Afrika speel 'n belangrike rol in die genesingsproses. Alhoewel die rol van die gemeenskap belangrik is, is baie vakkundiges egter onbewus van die negatiewe aspekte daarvan. Hierdie artikel beredeneer 'n kritiese beskouing van die genesingsrol van die gemeenskap in Afrika en bevraagteken gemeenskapsgenesing in die lig van 
pastorale genesing. Pastorale genesing as 'n spirituele en geloofsperspektief word gestel teenoor die tradisionele genesingsproses in Afrika-gemeenskappe. Aangesien hierdie twee gemeenskappe vanuit verskillende perspektiewe werk, is hulle in baie gevalle kompeterende kragte in die genesingsproses, wat erger pyn tot gevolg het. Hierdie artikel beskryf dus die proses van genesing vanuit sowel die geloofsgemeenskap (met sy dade van "koinonia") en die tradisionele Afrikagemeenskap en sluit af met 'n aanbeveling vir die integrering van die twee sisteme.

\section{Introduction}

The African extended family (or community) system plays a key role in the process of healing. In Kasambala' s dissertation The interplay between God-images and healing in pastoral ministry: engaging an African spirituality Kasambala (2004:95) rightly contends that "the African community is a service provider for a process of healing. For this reason, healing must be facilitated by the community". Kasambala' $s$ assertion is arguably a representative statement for many African scholars such as Berinyuu (1988); Mbiti (1975); Mwaura (2000) and others. However, while the role of community healing cannot be disputed, African scholarship on this kind of healing lacks a critical dimension. There seems to be an assumption that African community healing can easily be translated into or harnessed for effective pastoral ministry by the church.

However, it should be noted that the role of the community in the process of healing is also a distinctive character of pastoral care. Koinonia (the acts of believers' fellowship - the character of a faith community) implies a healing community. Bridger and Atkinson (1998:36), in line with many other scholars in the discipline of pastoral care like Augsburger (1986); Clinebell (1984); and Louw (1998), emphasise that within the Christian tradition the fundamental context for exercising pastoral care does not imply an individualistic relationship but the communal life of the body of Christ, the church.

Therefore, owing to the community approach of both African and pastoral healing systems of care, some African scholars propose a simplistic convergence of these approaches. Their argument, in fact, is unclear and confusing regarding what they mean by community healing (Mbiti, 1975; Ncube, 2003; Kasambala, 2004). The question within their approaches still remain: Do they refer to the traditional extended family or to the church community (with its acts of koinonia)? 
To gain clarity on the healing role of the community both in Africa and within the context of a faith community (and its associated koinonia), I argue that one should clearly distinguish between the healing practices of these communities. Such a distinction is crucial because although these community approaches may influence and borrow from each other, as Augsburger (1986) says, they operate from different perspectives. Their worldviews and resources are different. And worse, they may be competing forces in times of illness and suffering, which can lead to the aggravation or fanning of pain. In such instances the individual experiences intense tension between faith, the premise of pastoral care, and traditional African practices, the premise of the extended family. Hence, in such a situation I argue for a pastoral care approach through koinonia that provides a system of support that may substitute or function parallel to the traditional communal system to effect healing.

To develop a relevant pastoral ministry that effects healing in Africa, this article argues for an approach that is communal. Firstly, it outlines the distinctiveness of pastoral healing within the context of a faith community (with its acts of koinonia). Secondly, it describes the African worldview of illness and suffering, and the healing role of the extended family (community). Thirdly, it offers a critique of the often "romanticised" African healing process in the light of pastoral healing as a faith perspective. Fourthly, the article concludes by proposing a healthy integration of healing as exercised in the African traditional community and in a faith community - a process of healing that maintains the perspective of faith and the spiritual uniqueness of pastoral care.

\section{Pastoral healing: the faith community as a healing community}

The Greek word therapeia with the verb therapeuo, which is translated as to heal, cure or restore to health, also refers to service rendered by one to another (Thayer, 1984:288). Healing was integral to Jesus' ministry, hence pastoral care as a healing ministry is informed and rooted in Jesus Christ. De Gruchy (1989:39) draws an insightful link between healing and salvation. He argues that healing cannot be separated from the notion of salvation. Jesus and the early Christian community's healing ministry was integral for the proclamation of the kingdom. De Gruchy points out that healing in the Bible reflects a holistic understanding of humanity and reality. The concept of shalom is not only about the psychic and physical dimensions of a human being, but also about the social and political 
order. Therefore, De Gruchy connects salvation and healing as those processes which enable us to be fully human in relation to our society, our environment and ourselves. Both salvation and healing are indicators of healing and humanisation. The Bible reflects a holistic understanding of humanity and reality. Healing cannot be separated from the notion of salvation and peace (shalom). Hunter (1995:18) rightly states that pastoral care and counselling are conceived as a healing art, and the field as a whole has taken health and healing as its primary metaphor for a personal caring ministry.

Pastoral healing, as Louw (2003:213) further explains, is about salvation. The term cura animarum means cure of souls, and the soul is the qualitative principle of life (nefesh) as displayed within a very specific disposition or condition before God. Theologically, healing refers to the event of being transformed from a condition of death into a condition of life. This new condition is an indication of a new state of being: being accepted unconditionally by grace and being restored into a new relationship with God, a relationship of peace, reconciliation and forgiveness. Soul healing in pastoral care thus refers to pastoral acts and intentions that emanate from salvation. It opens up new avenues of understanding of our human vocation. It also refers to a sense of direction, which instils meaning and reflects the contextual implication of the gospel for life issues. Healing therefore is that which enables us to be fully human in relation to our society, our environment and ourselves.

In the medical professsion therapy is something different from what it implies in the helping professions. Medical science eradicates pain through medication, while the helping professions are concerned with treatment or help that is focused on healing and recovery through communication. This kind of treatment is intended to help the patient to gain insight, so that honesty about oneself (selfknowledge) can create an inner knowledge, which sets one free and brings healing. However, there is a difference between psychology and theology in understanding therapy. Louw (1998:443) describes the difference thus:

Psychotherapy concerns a person's personality functions and problems on an intra-psychic, inter-personal and contextual level. Pastoral therapy is primarily concerned with problems on a spiritual level: it focuses on people's functions of faith and their relationship with God. In so far as psychic, relational and contextual problems are at issue in pastoral care, they are connected to belief and the quest for meaning in life. Furthermore, growth and development in theology is not related 
to inner potential, but to the charismatic potential in the pneumatic person.

Pastoral healing, which Louw (1998:444) terms promissiotherapy, seeks to foster the maturity of a whole person in his/her totality. Its objective is spiritual maturity, faith development and growth. "Promissiotherapy is offered by the koinonia and is based on theology: God's faithfulness to his promises and the healing dimension of salvation." Schiller (cited by Louw, 1998:444) explains this phenomenon thus:

Salvation therapy includes liberation towards eternal communion with the Triune God, as well as a transformed attitude regarding the meaning of human life; a disposition of love for the fellow human being; courage and joy in life in trusting God; and hope for the future which endures throughout the process of dying and death. The therapeutic issue resides in the Christian's life once there is a living and committed relationship with Jesus Christ.

The context of pastoral healing is the community of faith. This context includes the Gospel's comforting and caring dimension. Pastoral healing is intensely concerned with the paracletic dimension of salvation. The characteristics of pastoral healing termed promissiotherapy by Louw, are outlined as follows:

- Pastoral healing is concerned with the paracletic dimension of salvation.

- Its context is koinonia, the acts performed by the community of faith (fellow-believers).

- The Gospel is central in this process - God's faithfulness to his promises.

- The goal of pastoral healing is to acquire maturity, faith development and growth.

I thus contend that pastoral healing as salvation healing entails a transformation of beliefs, values, and perspectives of an individual through the gospel. Pastoral care thus is about care for the whole person from a spiritual perspective. This care is concerned with a human being in its totality, and within a specific relationship: a faith relationship with God. The healing process through koinonia (acts of a faith community) aims to foster spiritual maturity and faith development. Crabb (1979:22) rightly states that the purpose of Christian counselling (or pastoral care) is "to free people to better 
worship and serve God by helping them become more like the Lord. In a word, the goal is maturity". Pastoral healing thus is about the paracletic dimension of salvation. The role of a faith community is to provide care and support as the person grapples with life issues within a faith understanding in order to cope and get meaning through Christian resources.

Against this background of pastoral healing within the context of koinonia (the acts of a faith community), I pose the following decisive question: how does the process of healing as effected by a faith community (and its comcomitant acts of koinonia) differ from that of the African community? To gain clarity on African community healing, I consider it in the light of the African worldview of illness, suffering and healing.

\section{African community healing in illness and suffering}

A worldview is the way that people see or perceive the world, the way they know it to be. It is man's idea of the universe. Michael Kearney's definition cited by Hesselgrave (1991:198) aptly sums up the meaning of worldview:

The worldview of a people is their way of looking at reality. It consists of basic assumptions and images that provide a more or less coherent, though not necessarily accurate, way of thinking about the world.

Kraft (1999) adds that people's worldview provides reasons and interpretation, it assigns meaning and gives explanations, it determines relations to others, adaptation to or decisions on life's issues such as illness, HIVIAIDS, nature, death, God, and everything else in life. In short, a worldview is the lens through which people view life.

Berinyuu (1988:49-50) in Pastoral care to the sick in Africa agrees with Forster's analysis of the African notion of illness, namely that it is personalistic. A personalistic medical system is one in which disease is explained as effected by the active purposeful intervention of an agent, who may be human (a witch or sorcerer), non-human (a ghost, an ancestor, an evil spirit), or supernatural (a deity or other very powerful being). The ill person is viewed as a victim, the object of aggression or punishment directed specifically against him. This view of illness is in contrast to the Western naturalistic system, which explains illness in impersonal, systemic terms. Disease is thought to stem, not from the machinations of an 
angry being, but rather from such natural forces or conditions as cold, or an upset in the balance of basic elements in the human body. Thus, supernatural causes are perceived as the causes of illness in Africa, while in the West illness is attributed to nonsupernatural causes.

Mwaura's (2000:72-119) article, Healing as a pastoral concern, further attests to the same causes of illness noted by Berinyuu. Illness is "often attributed to breaking of taboos, offending God and/or ancestral spirits; witchcraft, sorcery, evil eye passion by an evil spirit and a curse from parents or from an offended neighbour" (Mwaura, 2000:79). Ncube (2003:108) emphasises that this line of thinking has so great a command in people's lives that it would not be wise to ignore it. And focusing on the South African Zulu traditional way of coping and dealing with ukugula (illness), which may be representative of many Sub-Saharan African peoples, Ncube (2003:108) writes:

Many Zulus' illnesses are deliberately caused by enemies (izitha) or ancestral anger (ulaka Iwabaphansi/abadala) because of jealousy (umona) or neglect (ubudedengu) by family members. Hence the efficacy of the medicine is made possible by studying correctly one's surroundings and taking proper cautions.

However, apart from witches and sorcerers who predominantly have negative associations, all the other causes of illness result from breaking the equilibrium, which means one brings upon him/herself illness by breaking the balance. Therefore, when people are ill they consult diviners and sangomas (N'anga), who in turn advise them on the right sacrifices and initiations to appease the ancestors or spirits, thereby restoring the balance.

The personalistic view of illness and suffering, however, does not negate or diminish the naturalistic causes of illness such as germs, viruses or bacteria. Mwaura (2000:70) comments: "Though most Africans are aware that some illness has natural or organic causes, there is still an overriding belief in the supernatural or spiritual causation of illness." Therefore in seeking a cure one does not only rely on medication (herbs, injections and tablets), but this cure also includes mystical and spiritual remedies.

Many African writers share the idea that the African worldview should be taken seriously if one is to successfully minister to Africans including pastoral care. The argument is that the perception that illness is caused or always linked to supernatural causes should 
be taken as central. Mbiti's (1975:3) assertion in this regard is insightful:

Unless Christianity fully occupies the whole person as much as, if not more than, traditional religions do, most converts will continue to revert to their old beliefs and practices for perhaps six days a week, and certainly in times of crisis and emergency.

The above-mentioned approach is often the case regardless of education and upbringing, though this may vary. Hammond-Tooke's (1989:23) research on perceptions of the causes of illness in an African context reveals that $8 \%$ of rural and $7 \%$ of urban people believe that illness is caused by witchcraft. These perceptions indicate that there is little difference in perception between urban and rural Africans. It is crucial, therefore, to underline that people's worldview, though it may appear primitive and irrational, is the key to their understanding and interpretation of the world, and cannot easily be abandoned or ignored. Thus, for Africans any illness or suffering is always linked to supernatural causes.

Within this framework of illness and suffering, therefore, it is important to understand how healing is achieved within the extended family (or community). African counselling, which results in healing, Berinyuu (1989) states, is counselling where the community and the extended family corporately seek a solution to a crisis. Kiriswa (2002:26), in Pastoral counselling in Africa: an integrated model, rightly points out that life in traditional Africa is communal in character, and many stress-generating situations are solved before they overwhelm an individual. Everything revolves around the community where human relationships, conduct and moral integrity are constantly moulded, checked and controlled. Where there are misunderstandings or broken relationships that could lead to distress or illness, the community determines the process of guidance and counselling, which is often public as opposed to private. The community is the counsellor, healer and advisor. The African extended family system reinforces solidarity and coresponsibility among all members. Emphasis is laid on interpersonal relationships and moral support from all members of the family clan.

Furthermore, apart from community centredness and extended family counselling, preventative counselling is also common. Through initiation ceremonies young men and women are taught community expectations to prevent them from breaking community norms and values that would bring misfortune to them and the community. 
The cause of illness in Africa, as explained, is perceived to be through offending either God, ancestors, or through breaking a taboo or custom, which is believed to be a reason for punishment by God or the ancestors. At times illness is attributed to an offence against the gods, against spirits of the ancestors and the living dead, and other mysterious forces. At times it could be witchcraft, sorcery or enemies with magical powers to cast misfortunes (Berinyuu, 1988; Kasambala, 2004; Kiriswa, 2002; Mwaura, 2000).

In cases of illness, therefore, treatment is through ritual purification, exorcism or sacrifices. Correct relationships have to be maintained, starting with the nuclear family, moving outwards to the extended family, the clan, the tribe, gods, and spirits. Counselling is sought from the respective elders who then advise the individual or family on the appropriate rites, exorcism, sacrifice, purifications and confessions to restore the balance. Kiriswa (2002:30) observes that it is believed that without a ritual performance a person would not experience psychological healing. A ritual confirms that a person receives the necessary attention and healing.

African counselling (and healing), Kiriswa (2002) adds, is a type of hospitality only measured by the kindness, warmth and friendship of the counsellor. I argue that this approach parallels warmth in psychotherapy. Illness of any member in a community is never taken for granted. The health of a person is the responsibility of the whole community. The well-being of one means the well-being of all; when they celebrate, they do it together, and when death occurs, they grieve together. A healing ritual as a balance-restoring exercise signifies support, concern, love and a sense of belonging. Therefore to avoid things that may harm (destabilise) the system (balance), someone experienced and elderly should be consulted for counselling (advice) in order to preserve the community. That is why African traditional counselling is supposed to be done by specialised and experienced elders and not by young people.

Rituals that are performed to restore the balance are performed in a communal context. And through these rituals the ill person regains self-acceptance and a sense of belonging by realising that he/she is not alone on the journey of the challenges of life, and that there are people to support, encourage and confide in when trouble arises, a realisation which effects healing. But how does African community healing differ from pastoral healing? 


\section{African community healing vs. pastoral healing (faith community care - koinonid): a critique}

The contribution of African community healing cannot be exaggerated. The support and "being there for one another"-formula should be integrated into koinonial care (mutual care of believers) to encourage support of one another. Reconciliation fostered through community rituals is also invaluable in inculcating acceptance of one another despite their situation. However, the crucial African and pastoral healing question that we should pose is: how does pastoral healing differ from African communal healing, and can these two approaches be integrated?

In a useful way Kasambala (2004), focusing on African healing, underlines the crucial role of the community in Africa. He rightly argues that the African community is a service provider in the process of healing. However, what Kasambala, like other African counselling writers like Berinyuu, overlooks is the crucial complexity of community healing in Africa. Louw (1995:42), in the article Pastoral care for the person with AIDS in an African context, makes a valuable point but also adopts this simplistic assumption. Louw $(1995: 41)$ states:

For recovery, a pastoral approach should move away from a one to one pastor-patient relationship. An individual approach should be supplemented by group counselling, which must include the family, the social group and other important figures in the community as part of therapeutic process. The network of relationships from the illbed to the family, from the hospital to the community is even more important than the traditional bedside counselling with patients.

One major factor that causes Africans to oscillate between Christianity and traditional practices, thereby hindering pastoral healing, is community (extended family) pressure. When one goes through illness and suffering, the pressure to conform to community advice and practices that may be against pastoral or Christian practices is very high. Refusal to conform may cause expulsion from the circle of relationships, which aggravates pain and suffering. Ncube's (2003:91) observation that African healing is embedded in the realm of the extended family (community) practices is very valuable. The family or the community undertakes the journey (rituals and sacrifices) with the suffering person by being with the person, though the outcome may be inevitable as in the case of HIV and AIDS. He adds that the presence accorded to an individual 
either by rituals or community therapy confirms and confers some dignity on an individual. The person is never alone, confined in a hospital isolation room or hospice, but is always in the presence of the loved ones. He adds that, over and above this, there is an explanation, through divination, of the totality of one's situation.

Ncube, like other African writers, rightly identifies the crucial support and buffer that the African community provides, but he overlooks its other side. An individual is under the obligation to conform at all times. Ncube observes that it is imperative that an individual remains in a condition of peace with other living beings and the living dead; they deserve attention from an individual within the community (Ncube, 2003:91). Mbiti's (1975:2) comment is a key to understanding this African dynamic:

A person cannot detach himself from the religion of the group, for to do so is to be severed from his roots, his foundation, his context of security, his kinships and the entire group of those who make him aware of his existence. To be without one of these corporate elements of life is to be out of the whole picture.

Mbiti's observation clearly underlines the magnitude of the pressure that the African community can exert on an individual who is part of the system. And often the person conforms.

Msimang and Lamula (cited by Ncube, 2003:95) note:

It is in self-respect and performing one's duties that ikhaya (home) is dignified and its members are protected from all kinds of evil. In the spirit of inhlonipho nokuzinhlonipha (respect and self-respect) an individual within the family has responsibility to carry out his/her duties, that is, to behave according to the norms and traditions of the family.

The contentious question, however, is: what if respect, responsibility/duties or norms that one is expected to uphold are contrary to Christian values or principles of pastoral healing? Thus, in many cases it is difficult for an individual to hold exclusively to biblical teaching and understanding of illness and God, which is the premise of pastoral healing. In an African context this dilemma, therefore, poses enormous challenges to pastoral care. Pastoral care is much more complex and challenging than one may envisage. 
Pastoral healing in Africa is impossible if the counsellor does not determine either the positive or negative effects of the affected person's community (network of relationships). Pastoral healing, as mentioned, is about salvation. Healing refers theologically to the event of being transformed from a condition of death to a condition of life through God's unconditional grace in Christ. This state of new being entails a shift in thinking, which determines one' s response in illness and suffering. The thinking should be influenced through Scripture, thus embracing a biblical view of illness and suffering.

Illness and suffering triggers the "why?" question. In Meaning in suffering, Louw (2000:21) states that:

[i]n why? the concentrated grief of a finite is expressed to God: it is distressed cry for help and consolation. At the same time, the why? is an attempt to understand the enigma of suffering. For the unbeliever, why? can be an expression of total despair about the future that can eventually lead to a rejection of God. For the believer, why? is an indication of the struggle with God's justice in the midst of an experience of affliction, grief and guilt. It is an attempt to find a reasonable cause and solution.

However, when an African goes through illness and suffering, the "why"-question is preceded by "who?". An African wants to know "who" caused it (maybe a witch or ancestor), and then "why" it was done (possibly the ancestors are angry with the person). Ncube (2003:98), in referring to context of Zulu culture, also alludes to this African dynamic. He states that ukubhula (divination) offers an explanation of the cause of illness by the diviner and ukwelashwa (finding the cause of illness and appropriate treatment) gives hope of recovery. The laws of cause and effect concern the "who" of causation for Africans rather than the "what" of Westerners. Ukubhula addresses the who-ness of things around contamination by the virus. And in diagnosing the cause of the disease or misfortune, the diviner always discovers the cause either in witchcraft and sorcery and/or in the anger of the spirits.

The elders in Africa, as pointed out earlier, are the ones who advise an individual or family on the rightful people (diviners or healers) who are able to address the situation. In this sense, therefore, the elders' advice is taken seriously and one should embrace it. Refusal to act on the advice creates tension with the community. The person concerned would be considered to be community deviant. Thus, when an African asks the why-question, he or she receives an 
instant answer from a witchdoctor or diviner - which is slightly different from Louw's point of view.

Berinyuu (1989:63) sums up African healing as follows:

Your sickness, misfortune, or condition can be traced to either an inappropriate action by one member of the family or a conflict that existed among members of the family who may be dead. The purpose of the therapy is to say to the offender, you have done wrong or wrong was done by someone else, we have accepted responsibility, confessed the guilt/shame/ damage by an appropriate ritual. If it was a past conflict, descendants of the parties who gave rise to the conflict do the confession on behalf of the dead.

For pastoral healing to be effective in Africa, and within this African framework therefore, I hypothesise that a Christian/biblical worldview or understanding should be in place. This entails what I would call "culture or worldview metanoia", which Keteyi (1998:38) calls a cultural process of conversion. Pastoral healing is concerned with individuals and is applied from a spiritual perspective. As such, pastoral healing utilises resources unique to the Christian faith (Holy Spirit, Scripture, prayer, sacraments, faith community).

In this regard, therefore, the African worldview that answers the why-question (cause and effect) should be shifted (metanoia) to a biblical understanding that contends with God's transcendence, and with human fallibility and limitations. We will not always know why we suffer. Thus the African notion that every illness is linked to a supernatural cause should be seriously challenged. This approach, however, does not negate or deny the influence of evil powers, because to deny their influences would be denying Scripture. The point being made is that such an inquiry into the "who-ness or whyness" is forbidden in Scripture (Lev. 19:26; Ezek. 13:20; Rev. 21:8; $22: 15)$ and it creates enmity among people, especially close relatives. An African Christian, therefore, should embrace the biblical view of suffering and illness, which is crucial for the pastoral healing process.

In light of the above discussion, I pose the following questions: what then is the role of pastoral care in Africa? How can the African traditional community and the faith community (with its acts of koinonia) be integrated in order to bring about effective pastoral ministry? Integration refers to a systematic incorporation of some African extended family or community healing practices in pastoral 
caring. It does not refer to blending African practices with Christianity.

\section{Towards integrating extended family (community) care and the pastoral care of a faith community in Africa}

The notion of the extended family (community) in Africa is commonly called ubuntu. An individual does not exist on his/her own, for a person is a person through and with others (umunthu ungumuntu ngabantu), and this view is invaluable for the church. In the Christian tradition Christians live as the body of Christ (1 Cor. 12) - a way of life which encourages connectivity among congregational members (the expression of koinonia), thereby providing support for ill and suffering people. Furthermore, the tradition of being present and observing someone who is ill makes caring imperative, both from a cultural and Scriptural point of view. One has to be present or continuously visit the ill person. Also, the practice of according a person respect and dignity throughout life, preventing the person from becoming a wandering spirit because he/she was not given love, can be harnessed to encourage acceptance, love and care for people, because all people are created in the image of God. These ethics should be encouraged in the Christian church.

However, within an African context, where a person views himself as part of a community that exerts an influence on him/her, how is it possible for one to break from the community system and then have the assurance that God protects him/her? How could one refuse community advice, especially from the elders who are perceived to be the rightful people to advise an individual on the right ritual or diviner and still get healed? Is it possible to think of God concretely, so that people who are in tension with their traditional family community still receive community healing?

Salvation and healing in Africa, Okoye (2005) argues, is not about the future and individualistic in nature, as the missionaries explain it, but about the present, and is communal and holistic in nature. Salvation and healing are about the well-being and possession of life in its fullest potency. When one goes against one's family and one's community ancestors through rebellion and deviance, one needs daily salvation derived from the world of spirits. Therefore, in such a case the sufficiency and omnipresence of God should be concretely communicated and embodied in order to bring healing. 
The appropriate way to think of God in suffering is to focus on His Son Jesus Christ. By focusing on Jesus Christ, one would view God in terms of His identification with human needs and suffering (pathos). One should not fear the threat of evil spirits or any other supernatural forces.

Pastoral care-givers in Africa, therefore, should identify metaphors and descriptions in Scripture which depict God in terms of his identification with human illness and suffering. These metaphors should not only be communicated but also embodied. The following metaphors could be applied: the good shepherd (solicitous care), and the suffering servant (God's pathos). The view of God regarding man's "wisdom" as "foolishness" (the presence of God through paradox), and the view of God acting as paracletos (with its implied meanings of guiding, encouraging, empowering, consoling, sustaining, and reconciliation, can also be applied) (Capps, 1984:66-69; Louw, 1998:39-54).

God the good Shepherd is always present to protect his sheep (Ps. 23); He identifies with a person in his/her situation, thereby bringing healing (suffering servant) (Is. 52:13-53:12); He challenges the tendency to maintain a cause and effect approach to illness and suffering (man's "wisdom" regarded by God as "foolishness") (1 Cor. $1: 18-25$ ); and is as perecletos always present to encourage (cf. John 14-16). These metaphors and descriptions of God depict his involvement in people's situations of illness and suffering. Pastoral care-givers who are members of a faith community (and exercise deeds of koinonia), should not only concentrate on inculcating faith in God, who identifies with his people as evidenced in his Son, but should also embody these metaphors. These metaphors and descriptions perceived in communal terms, as in the African context, challenge and encourage mutual care and the interdependence of believers. They foster the idea of a God who is a friend, partner and companion for life through day-to-day fear of the world of spirits. And when one is in tension with the traditional community, one should find a "hidden nest" among fellow believers (the faith community that persevere in exercising koinonia). Fellow believers encourage and comfort him and are his companions, thereby replacing the healing role of the traditional community and extended family.

The challenge, however, lies in confronting someone's worldview in order to conform to biblical thinking, while at the same time extended family and community pressure occur. Whichever decision the person makes is painful. Should he/she follow the biblical way 
and go against the community elders, or should he follow the elders and forsake the Christian faith?

I strongly recommend that, for pastoral care to be relevant in Africa, it should maintain and emphasise the communal dimension. This kind of care views a person not in isolation, but within a network of relationships, a fellowship of believers. Pastoral care among the ill and suffering that embraces biblical thinking and appropriate Godimages in Africa could entail conflict with the network of relatives and traditional practices, and the person's risk of being cut off. Pastoral care through koinonia, therefore, should always be ready to support the person materially and spiritually. This care entails creating a support base of hope. Koinonia should replace the broken network with relatives, but at the same time the person should not become detached from his or her relatives.

\section{List of references}

AUGSBURGER, D.W. 1986. Pastoral counselling across cultures. Philadelphia: Westminster.

BERINYUU, A.A. 1988. Pastoral care to the sick in Africa: an approach to transcultural pastoral theology. Frankfurt: Peter Lang.

BERINYUU, A.A. 1989. Towards theory and practice of pastoral counselling in Africa. New York: Peter Lang.

BRIDGER, F. \& ATKINSON, D. 1998. Counselling in context: developing a theological framework. Darton: Longman \& Todd.

CAPPS, D. 1984. Pastoral care and hermeneutics: theology and pastoral care. Philadelphia: Fortress.

CLINEBELL, H. 1984. Basic types of pastoral care counselling: resources for the ministry of healing and growth. Nashville: Abingdon.

CRABB, L.J. 1979. Effective biblical counseling. Michigan: Grand Rapids.

DE GRUCHY, J. 1989. Salvation as healing and humanisation. (In Hart, T.A. \& Thimell, D.P., eds. Christ in our place: the humanity of God in Christ for the reconciliation of the world. Exeter: Paternoster. p. 32-47.)

HAMMOND-TOOKE, D. 1989. Rituals and medicines. Johannesburg: Donker.

HESSELGRAVE, D.J. 1991. Communicating Christ cross culturally: an introduction to missionary communication. Michigan: Zondervan.

HUNTER, R.J. 1995. The therapeutic tradition of pastoral care and counselling. (In Hunter, R.J., ed. Pastoral care and social conflict. Nashville: Abingdon. p. 17-31.)

KASAMBALA, A.E. 2004. The interplay between God-images and healing in pastoral ministry: engaging an African spirituality. Stellenbosch: University of Stellenbosch. (D.Th. dissertation.)

KETEYI, X. 1998. Inculturation as a strategy for liberation. Pietermaritzburg: Cluster Publications.

KIRISWA, B. 2002. Pastoral counselling in Africa: an integrated model. Eldoret (Kenya): AMECEA Gaba. 
KRAFT, C.H. 1999. Culture, woldview and contextualization. (In Winter, R.D. \& Hawthorne, S.C. Perspectives on the world Christian Movement. 3rd ed. California: William Carey Library. p. 384-391.)

LOUW, D.J. 1995. Pastoral care for the person with AIDS in an African context. Journal of Practical Theology in Southern Africa, 10(1):29-44.

LOUW, D.J. 1998. A pastoral hermeneutics of care and encounter. Cape Town: Lux Verbi.

LOUW, D.J. 2000. Meaning in suffering: a theological reflection on the cross and the resurrection for pastoral care and counselling. Wissenschaften: Peter Lang.

LOUW, D.J. 2003. The healing dynamics of space: relational and systemic therapy in pastoral care to people suffering from poverty. (In Couture, P.D. \& Miller-McLemore, B., eds. Poverty, suffering and HIVIAIDS: international practical theological perspectives. Fairwater: Cardiff Academic Press. p. 209-218.)

MBITI, J.S. 1975. African religions and philosophy. London: Heinemann.

MWAURA, P.N. 2000. Healing as a pastoral concern. (In Waruta, D.W. \& Kinoti, H.W., eds. Pastoral care in African Christianity. Nairobi: Acton Publishers. p. 72-100.)

NCUBE, V.S. 2003. Responsibility in inculturation: the healing ministry in a Zulu context. (In Bate, S.C., ed. Responsibility in a time of AIDS: a pastoral response by Catholic theologians and AIDS activists in Southern Africa. Pietermaritzburg: Cluster Publications. p. 24-40.)

OKOYE, J.C. 2005. African theology. www unituebingen.de/INSeCT/african/ okoye.html Date of access: 6 Dec. 2006.

THAYER, J.H. 1977. Greek-English Lexicon of the New Testament. Michigan: Baker Book House.

\section{Key concepts:}

Christian healing in Africa

community healing

pastoral care and the extended family

pastoral care in Africa

pastoral healing in Africa

\section{Kernbegrippe:}

Christelike genesing in Afrika

gemeenskapsgenesing

pastorale genesing in Afrika

pastorale sorg en die uitgebreide familie

pastorale sorg in Afrika 
